\title{
Spatial Diversity of Macrobenthic in Ngenep Spring Due to Anthropogenic Activities
}

\author{
Ekwan N. Wiratno*, Rizky Nurdiansyah, M. Basyaruddin, Slamet Riyanto, Novie S. Rupilu, \\ Catur Retnaningdyah
}

Department of Biology, Faculty of Mathematics and Natural Sciences, University of Brawijaya, Malang, Indonesia

\begin{abstract}
This aims of this study are to determine the macrobenthic community structure between the drainage near residence and spring; and to determine effect of local environment on macrobenthic community structure at the Ngenep village. Field study was conducted in 3 drainage, i.e. residential drainage, spring and rice field irrigation. Macrobenthic were sampled by the surber net and hand net in three stations in each drainages. Abiotic factors were assessed at the same stations. Macrobenthic community structure and diversity was determined using Important value index, ShannonWiener index and Bray Curtis index. Cluster of benthics and abiotic factors were analysis using Principal Component Analysis (PCA). Abiotic data showed no statistical significance in 3 drainage $(P>0.05)$ but showed increasing trend from spring to field irrigation and the highest at residential drainage. The 17 taxa of macrobenthic were found with high important value index are Melanoides tuberculata, larva's of Ephemeroptera and Plecoptera. Highest Shannon-Wiener index observed at irrigation (2.781). The cluster analysis of abiotic factor showed that spring was in different cluster with residential and irrigation, meanwhile, PCA analysis of macrobenthic showed each place was different cluster. Conclusion of this study is anthropogenic activities alter the diversity and community structure of macrobenthic.
\end{abstract}

Keywords: Anthropogenic Activity, Macrobenthic, Ngenep.

\section{INTRODUCTION}

Ngenep villages, Malang Regency, East Java, Indonesia have a spring and the water is utilized for many things. Most of the citizen in Ngenep are farmers $(3,911$ people from 13,499 people) and use the water for agricultural purposes and daily purposes such as bath and laundry [1]. Anthropogenic activities in Ngenep village may alter the water quality. Bioindicator organism, such as plankton, benthic macroinvertebrates or fish may be employed to assess the aquatic commu-nity quality and water quality. Benthics are effective tools for environment health assessment; these are easy, cost-effective, and quick assessment [2].

Macrobenthic are the organism that dwells in the bottom of the water body. These organisms have role in water mineralization process, assist the water organic material cycle, and become the linking chain between plankton and peryphiton to higher tropic level in aquatic community. Many studies used macrobenthic as the bioindicator of water quality because of its relatively easy to conduct, inexpensive, and because of its limited migratory pattern able to give better water quality assessment. Anthropogenic land-based activities such as urban runoff were

\footnotetext{
* Correspondence address:

Ekwan N. Wiratno

Email : ekwanwiratno@gmail.com

Address : Jl. Veteran Malang 65145, Malang.
}

given impact on the distribution and species diversity of macrobenthic invertebrates [2]. Ngenep are one of the most spring sites at Malang and near human residence.

The aims for this study are to determine the community structure of the macrobenthic between the drainage that built near the residence and spring; and to determine the effect of local environment to macrobenthic community structure. The data of the study are expected as the reference to water remediation and conservation management for near human dwellingwater bodies.

\section{MATERIALS AND METHODS}

\section{Study Sites and Benthic Sampling}

Ngenep Village, Malang City is located at $7^{\circ} 44^{\prime}-8^{\circ} 26^{\prime} \mathrm{LS}$ and $112^{\circ} 17^{\prime}-122^{\circ} 57^{\prime} \mathrm{BT}$ with highland topography at $250-500 \mathrm{~m}$ asl elevation. The study was conducted in November 2013. Field study was conducted in 3 drainages; (1) the stream of drainage near the human residence, (2) the stream near the spring and (3) the stream near the field irrigation. The spring is the source of water in the drainage.

Macrobenthic was sampled using surber net and hand net in 3 stations, based on selective sampling, which categories are substrates differences and riparians. Collected macrobenthic was sorted using pinset and white plate and then preserved with $70 \%$ ethanol in labeled sterile vials. Identification is conducted in Ecology 
and Animal Diversity Laboratory at Department of Biology, University of Brawijaya using the stereo microscope and reference literature $[2,3,4]$.

\section{Abiotic Factor Measurements}

Abiotic factors are measured at the same stations and triplicate. The measured factors are: water temperature $\left({ }^{\circ} \mathrm{C}\right)$ using thermometer; stream velocity $\left(\mathrm{m} . \mathrm{s}^{-1}\right)$; conductivity ( $\mu$ mhos) using conductivity meter; water $\mathrm{pH}$ using digital $\mathrm{pH}$ meter; Dissolved oxygen (DO) (mg. $\left.\mathrm{L}^{-1}\right)$ using digital DO-meter [4,5], DO data were used to measure the water BOD; Total Organic Matter (TOM) [6]; water turbidity using turbidity meter; water nitrate content (mg. $\mathrm{L}^{-1}$ ) method [7]; and water orthophosphate content $\left(\mathrm{mg} \cdot \mathrm{L}^{-1}\right)$ method [8]. We also slightly described the stream substrate using direct observation.

\section{Data Analysis}

Macrobenthic community structure is determined using: (1) Important value index to determine the relative importance of each species; (2) Shannon-Wiener index to estimate the community diversity; and (3) Bray Curtis index to estimate the dispersal and similarity of macrobenthic [5,9]. Principal component analysis (PCA) for abiotic factor and macrobenthic were employed with PAleontological STatistics (PAST) program. ANOVA analysis is employed using SPSS 16.0 for Windows.

\section{RESULT AND DISCUSSION \\ Abiotic Factor}

The abiotic data from three water bodies showed no significant differences $(P>0.05)$ for almost the entire factor. The only difference was water at residential drainage have faster velocity than the other (Suppl.1). Although the abiotic factors have no statistical differences, there are some trends that occur. DO, BOD, conductivity, TOM, and turbidity have increasing pattern from spring to field irrigation and the highest at residential drainage.

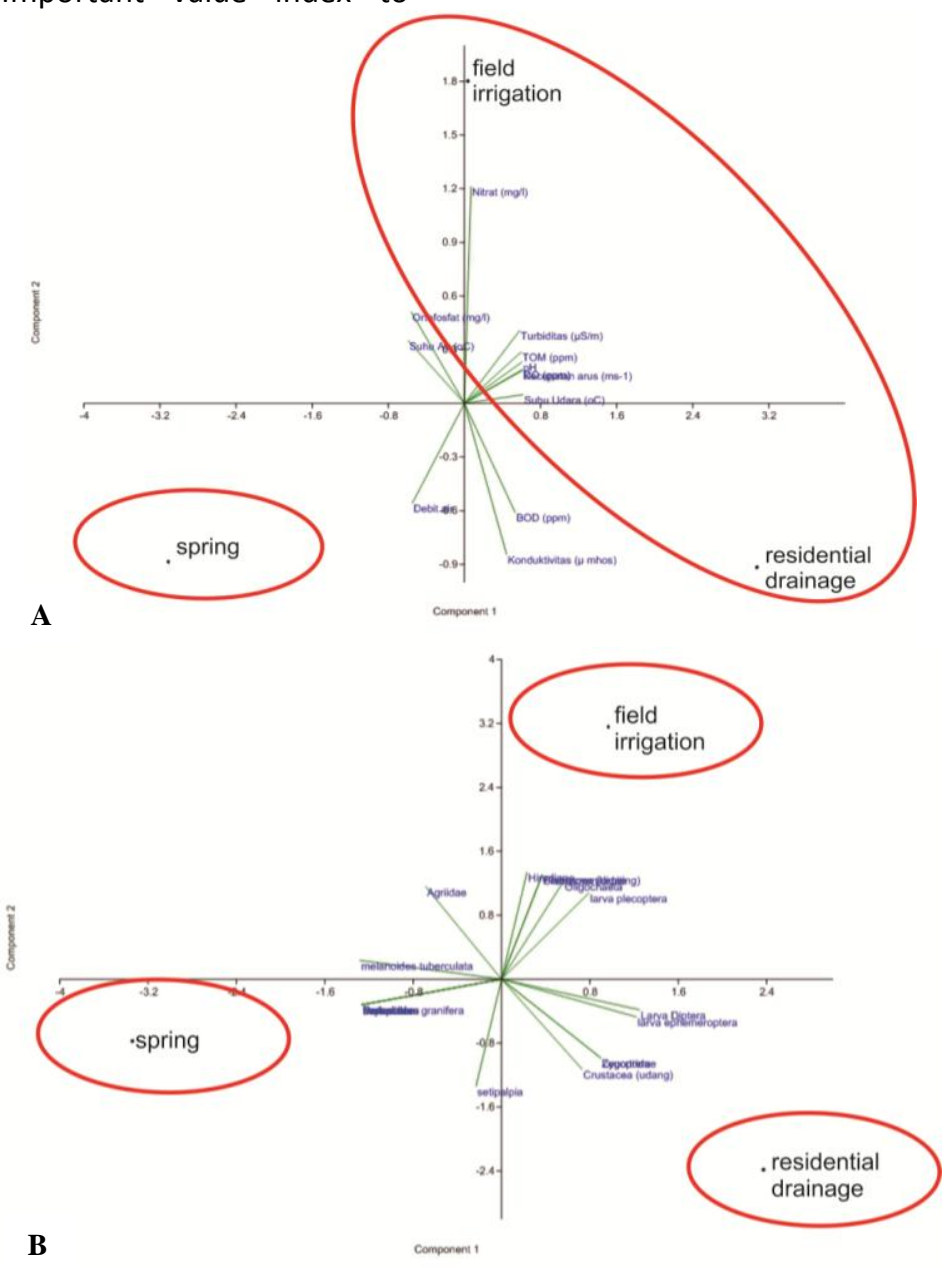

Figure 1. PCA Analysis of Abiotic Factor and Macrobenthic of 3 Water Bodies at Ngenep Village A: Abiotic Factor; B: Macrobenthic 
Cluster analysis and PCA showed that irrigation and residential drainage have very high similarity (93\%) (Suppl. 2) and it became the same cluster with $80 \%$ threshold. It suggested that the spring have different quality, and anthropogenic activity may one of the causes. Biplot of PCA showed that many abiotic factors have tendency to the irrigation and residential cluster. Nitrate content is highly positive correlated to irrigation. Water debit is positively correlated to water spring (Fig. 1).

Anthropogenic activity near the spring does not have considerable impact based on the abiotic data. The increasing trend of DO, BOD, conductivity, TOM, and turbidity are mediated by anthropogenic activity, but no significant ( $P>$ 0.05). Increased conductivity is result of human impacts such as organic pollution and nutrient enrichment [10]. Turbidity usually goes around with conductivity patterns [11].

\section{Benthic Community Structure}

We found 17 taxa of macrobenthic from three drainages with the most found taxa are Melanoides tuberculata, larvae of Ephemeroptera and Plecoptera (Fig. 2). The high observed Shannon-Wiener index was observed at irrigation (2.781), resident drainage (2.554) and spring (2.064) (Fig. 3).

Shannon Wiener diversity index value showed that every water bodies have value more than 2 , which is considered good. The community stability in the three places is not easy to change if there are slight disturbances from the environment. Lower diversity index in water spring may caused by the substrate. Most of the substrate at the water spring are sand, meanwhile the others are rocky and slight sand. Sandy environment have less diversity than rocky, and most of them are suspended feeder or carnivores such as Polychaeta, Bivalvia and Crustaceas [12]. We found many M. tuberculata (Bivalvia) in spring.

Cluster analysis using Bray Curtis Index and principal component analysis (PCA) were conducted to determine the dispersal of the macrobenthic (Fig. 1). The data showed that three water bodies have different macrobenthic based on $80 \%$ similarity and become three different clusters (Suppl. 3). The data suggest that antrophogenic activity alters the macrobenthic community stronger than the abiotic factor.

The oxygen concentration was the most important factor for Ephemeroptera, Coleoptera, Trichoptera, Hemiptera, Odonata, Diptera and Hydropsychidae. The BOD was the most important factor for Hydrophilidae and Hirudinea, whereas the turbidity for Collembola [13]. The water spring have the lowest DO between the three and have less Ephemeroptera.

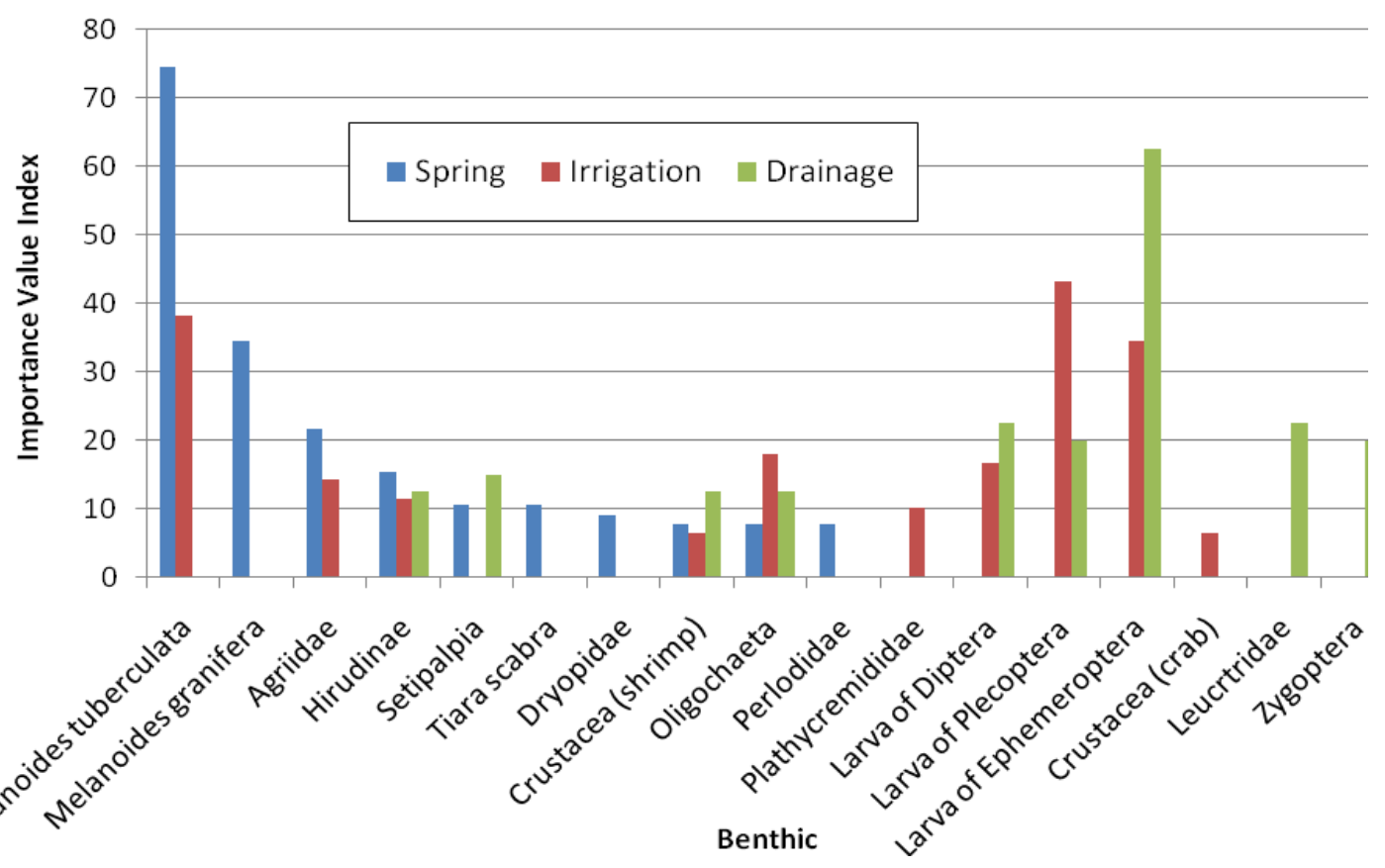

Figure 2. Important Value of Macrobenthic in three types of drainage at the Ngenep Village 


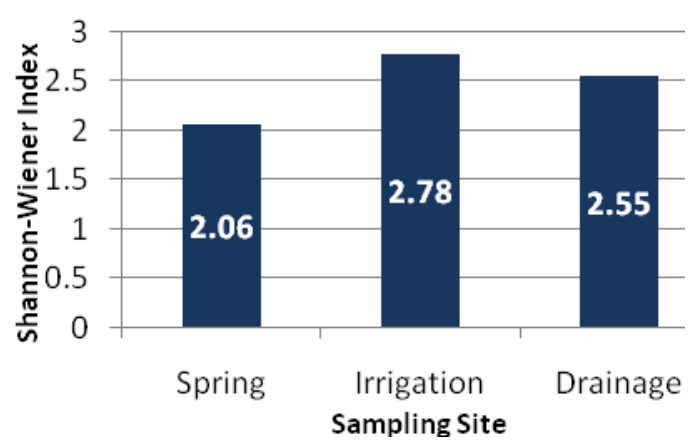

Figure 3. Shannon-Wiener Diversity Index of Spring, Irrigation and Residential Drainage

Melanoides tuberculata is dominant benthos in spring, larva of Ephemeroptera in irrigation and larva of Plecoptera in recidential drainage. M. tuberculata intimately correlated with the physico-chemical factors of the water. These species can be considered as bioindicators pollution (organic pollutant was produced by animals and humans) because they possess great tolerance against the contaminants present in water [14].

The Ephemeroptera are sensitive benthic and usually are indicators of good water quality [15]. The most of Ephemeroptera larvae have very narrow requirements regarding their tolerance to dissolved oxygen, $\mathrm{pH}$, type of substrate, size and currents of the stream, and temperature of the water [16]. Most of the Plecoptera species are sensitive to pollution due to low levels of adaptive mechanisms [17].

\section{CONCLUSION}

The 17 taxa of macrobenthics were found with high important value index are Melanoides tuberculata, larva of Ephemeroptera and Plecoptera. The high observed Shannon-Wiener index was observed at irrigation (2.781), resident drainage (2.554) and spring (2.064). PCA analysis of abiotic factor showed that spring was in different cluster with residential and irrigation, meanwhile, PCA analysis of macrobenthic showed that each place has different cluster. Anthropogenic activities alter the diversity and community structure of macrobenthic.

\section{ACKNOWLEDGEMENT}

The authors gratefully acknowledge the contributions of Purnomo, Hamdani Dwi P., Tiara Ayu P., and R. Ayu S, for assistance at field sampling; Zidny Furaidah and Hamdani Dwi P., for assistance in data analysis.

\section{REFERENCES}

[1] Machfudz, M. and N. Khoiriyah. 2013. Analisis ketahanan pangan melalui pemodelan usaha tani singkong. Islamic University of Malang (UNISMA). Malang.

[2] Barbour, M.T., J. Gerritsen, B. D. Snyder and J. B. Stribling. 1999. Rapid bioassessment protocols for use in streams and wadeable rivers: Peryphiton, Benthic Macroinvertebrates, and Fish. U.S. Environmental Protection Agency, Washington D.C.

[3] Lupi, D., A. Rocco and B. Rossaro. 2013. Benthic macroinvertebrates in Italian rice fields. Journal of Limnology 72(1): 184-200.

[4] Sinaga, T. 2007. Keanekaragaman makrozoobentos sebagai indikator kualitas perairan Danau Toba Balige, Kabupaten Toba Samosir. Thesis. University of North Sumatra, Medan.

[5] Puspitasari, S., E. Arisoesilaningsih and B. Yanuwiadi. 2011. Pemetaan aktivitas masyarakat dan kualitas abiotik perairan Ranu Grati, Kabupaten Pasuruan. Thesis. Department of Biology, University of Brawijaya. Malang.

[6] Prasetyo, H.D. and C. Retnaningdyah. 2013. Penggunaan diversitas vegetasi riparian lokal untuk peningkatan kualitas air irigasi tersier di Desa Kedung Pedaringan Kecamatan Kepanjen Kabupaten Malang. Thesis. Department of Biology, University of Brawijaya. Malang.

[7] Narayana, B. and K. Sunil. 2009. A spectrophotometric method for the determination of nitrite and nitrate. Eurasian Journal of Analytical Chemistry 4(2), 204- 214.

[8] Feiser, L. F. and M. Feiser. 1967. Reagents for organic synthesis. Wiley and Sons Inc. New York.

[9] Merganic, J. and S. Smelko. 2004. Quantification of tree species diversity in Forest Stands-Model BIODIVERSS. Europe Journal of Forest Research 123, 157-165.

[10] Sutherland, B. A., J. L. Meyer and E. P. Gardiner. 2002. Effects of land cover on sediment regime and fish assemblage structure in four southern Appalachian streams. Freshwater Biology 47, 1791-1805.

[11] Kasangaki, A., L. J. Chapman and J. Balirwa. 2007. Land use and the ecology of benthic macroinvertebrate assemblages of highaltitude rainforest streams in Uganda. Freshwater Biology 53(4), 1-17. 
[12] Barnes, R. S. K. and R. N. Hughes. 1999. An introduction to marine ecology $3^{\text {rd }}$ Edition. Blackwell Ltd. London.

[13] Souto, R. M. G., K. G. Facure, L A. Pavanin and G. B. Jacobucci. 2011. Influence of environmental factors on benthic macroinvertebrate communities of urban streams in Vereda habitats, Central Brazil. Acta Limnologica Brasiliensia 23(3), 293-306.

[14] Sharma, K. K., K. Bangotra and M. Saini. 2013. Diversity and distribution of Mollusca in relation to the physico-chemical profile of Gho-Manhasan stream, Jammu (J \& K). International Journal of Biodiversity and Conservation 5(4), 240-249.

[15] Junqueira, V. M. and S. C. M. Campos. 1998. Adaptation of the "BMWP" method for

\section{SUPPLEMENTARY}
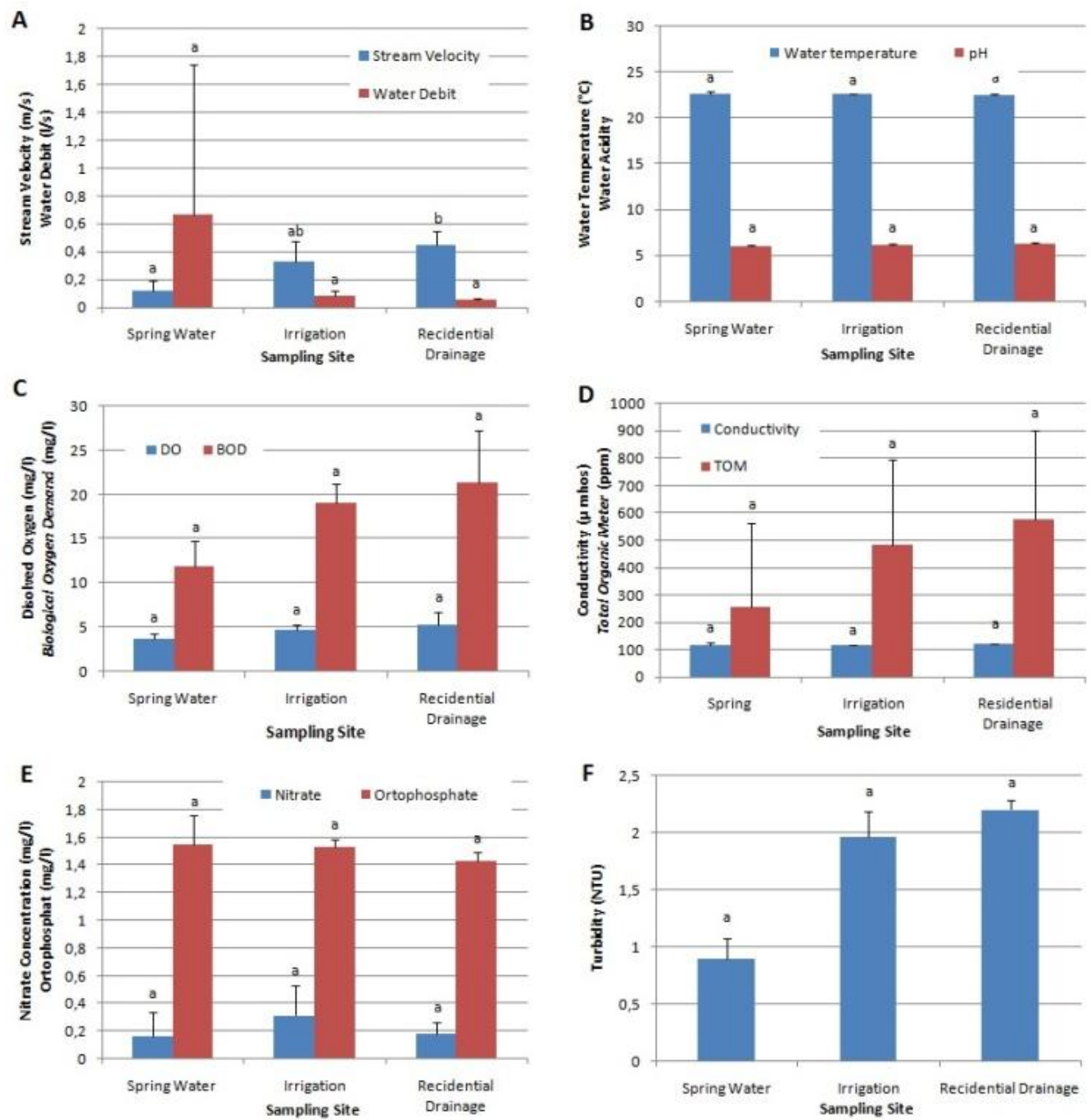

Supplementary 1. Abiotic Factors in Each Drainage Type of Ngenep Village, Karangploso

A. Stream Velocity and Water Debet; B. Water Temperature and Water Acidity; C. DO and BOD; D. Conductivity and TOM; E. Nitrate and Orthophosphate Concentration; and F. Turbidity. Bars are Standard Deviation. Notation shows statistical different at $\mathrm{P}>0.05$. 


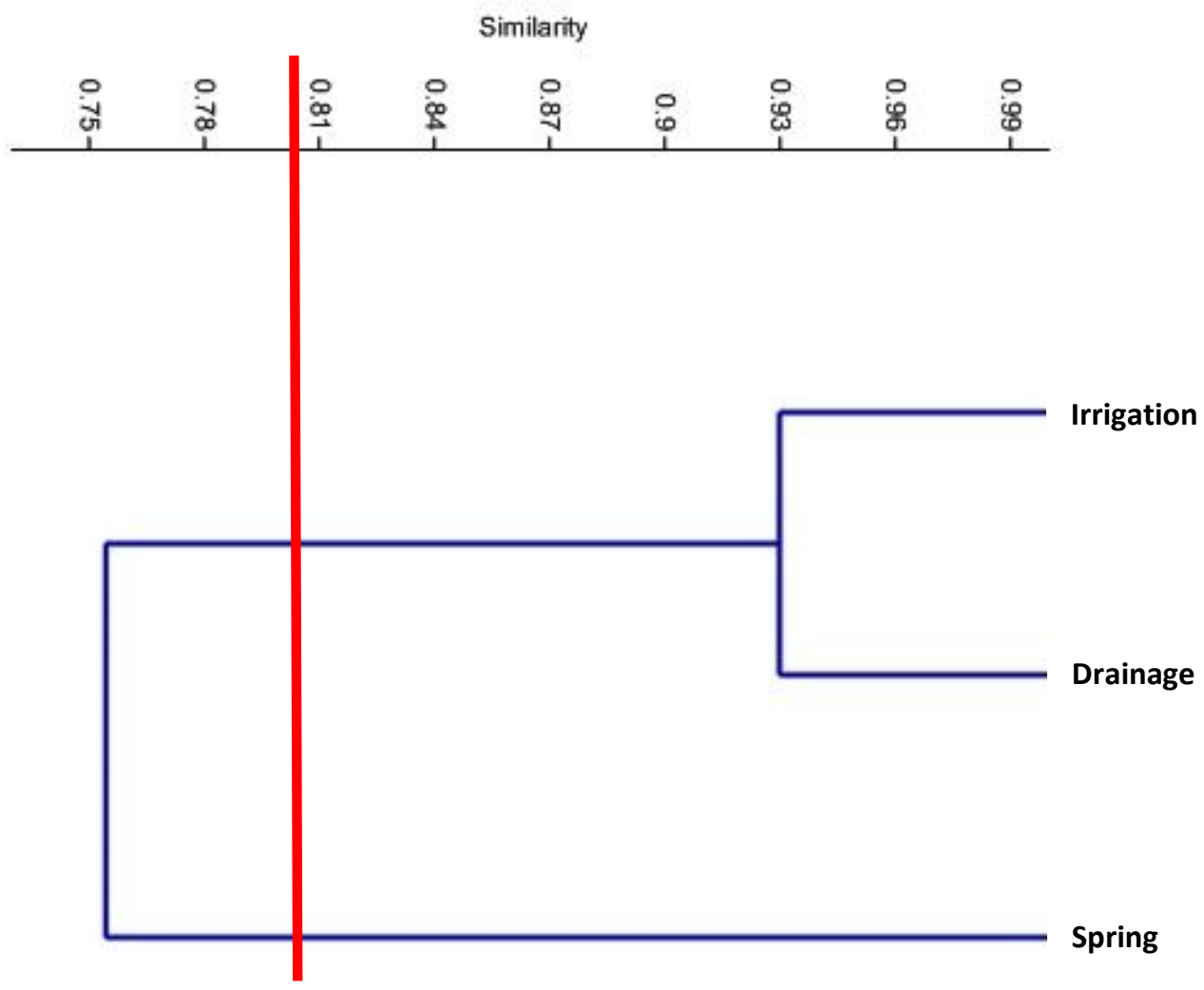

Supplementary 2. Cluster Analysis of Abiotic Factor Based on Bray Curtis Similarity Index in 3 Water Bodies at Ngenep Village. Red Line Indicates Clustering at $80 \%$ Similarity

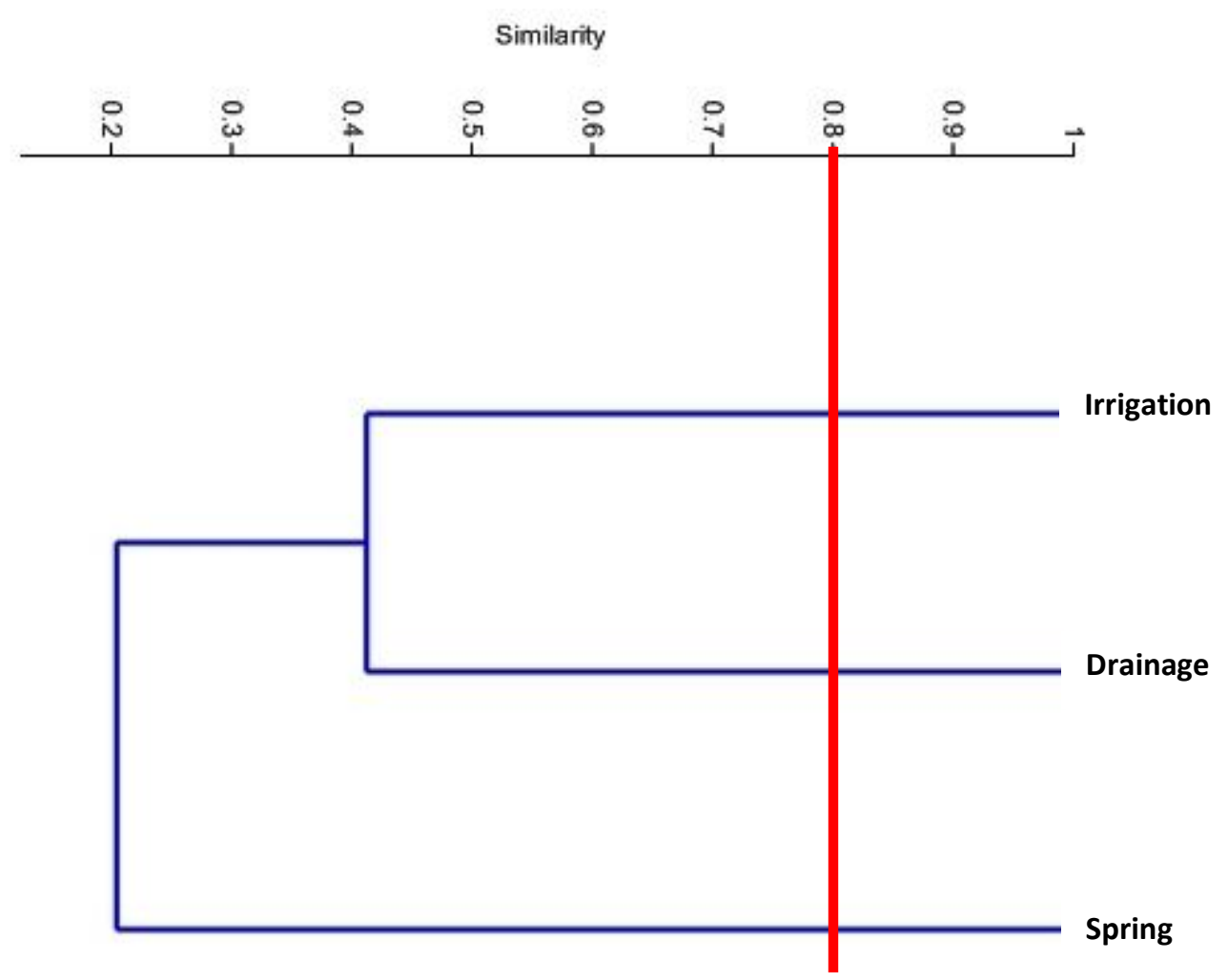

Supplementary 3. Cluster Analysis of Macrobenthic Based on Bray Curtis Similarity Index in 3 Water Bodies at Ngenep Village. Red Line Indicates Clustering at $80 \%$ Similarity 